\title{
Antioxidant and Antidiabetic Effect of Aqueous Fruit Extract of Passiflora ligularis Juss. on Streptozotocin Induced Diabetic Rats
}

\author{
Palanirajan Anusooriya, ${ }^{1}$ Deivasigamani Malarvizhi, ${ }^{1}$ \\ Velliyur Kanniappan Gopalakrishnan, ${ }^{1,2}$ and Kanakasabapathi Devaki ${ }^{1}$ \\ ${ }^{1}$ Department of Biochemistry, Karpagam University, Coimbatore, Tamil Nadu 641 021, India \\ ${ }^{2}$ Department of Bioinformatics, Karpagam University, Coimbatore, Tamil Nadu 641 021, India \\ Correspondence should be addressed to Kanakasabapathi Devaki; dr.devaki.bc@gmail.com
}

Received 20 June 2014; Accepted 2 December 2014; Published 21 December 2014

Academic Editor: Changyang Gong

Copyright @ 2014 Palanirajan Anusooriya et al. This is an open access article distributed under the Creative Commons Attribution License, which permits unrestricted use, distribution, and reproduction in any medium, provided the original work is properly cited.

\begin{abstract}
Diabetes mellitus is the most common endocrine disorder that impairs glucose homeostasis resulting in severe diabetic complications including retinopathy, angiopathy, nephropathy, and neuropathy causing neurological disorders due to perturbation in utilization of glucose. Hypoglycemic activity was detected in aqueous extract of Passiflora ligularis, a traditionally used medicinal plant, using streptozotocin (STZ, $30 \mathrm{mg} / \mathrm{kg}$ body weight) induced diabetic rat model. Oral administration of aqueous extract of Passiflora ligularis to diabetic rats for 30 days resulted in a decrease in blood glucose. The diabetic rats had decreased levels of serum total protein, albumin, globulin, and albumin/globulin ratio as compared to control rats. In addition, the activities of hepatic and renal markers were significantly elevated in diabetic rats as compared to control rats. Treatment with aqueous fruit extract of $P$. ligularis and glibenclamide reversed these parameters to near normal. Extract at a dose of $400 \mathrm{mg} / \mathrm{kg}$ given orally for 30 days showed significant elevation in enzymatic (SOD, catalase, and Gpx) and nonenzymatic antioxidants (vitamin C, vitamin E, and reduced glutathione). Plant extract treated groups showed significant decrease in lipid peroxidation (LPO). Aqueous extract of Passiflora ligularis fruit can decrease the blood glucose and reduce the oxidative stress by removing free radicals in diabetes.
\end{abstract}

\section{Introduction}

Diabetes mellitus is a metabolic disorder in which a combination of hereditary and environmental results in abnormally high blood sugar levels (hyperglycemia). The abnormal high blood sugar level is due to defects in either insulin secretion or insulin action in the body [1]. Diabetes mellitus is characterized by hyperglycemia, lipoprotein abnormalities, raised basal metabolic rate, defect in enzymes, and high oxidative stress which induced damage to pancreatic beta cells. It is the most common endocrine disorder that impairs glucose homeostasis resulting in severe diabetic complications including retinopathy, angiopathy, nephropathy, and neuropathy and causing neurological disorders due to perturbation in utilization of glucose [2].

Currently, in the United States, up to 1 in 3 new cases of diabetes mellitus diagnosed in youth younger than 18 years is $\mathrm{T} 2 \mathrm{DM}$, with a disproportionate representation in ethnic minorities, occurring most commonly among youth between 10 and 19 years of age. This trend is not limited to the United States but is occurring internationally; it is projected that by the year 2030, an estimated 366 million people worldwide will have diabetes mellitus [3]. The number of individuals with type 2 diabetes mellitus (T2DM) is increasing with a rate of three new cases every ten seconds [4], and it is being diagnosed at younger age. Multiple risk factors behind the disease include chronic stress and depression, environmental pollutants and poisons, obesity and overnutrition, and sedentary life style [5]. India having the highest number of diabetic patients in the world, the sugar disease is posing an enormous health problem in the country. Calling India the diabetes capital of the world, the International Journal of Diabetes in Developing Countries says that there is alarming rise in diabetes in India. An estimated 3.4 million deaths occur due 
to consequences of high blood sugar. WHO also estimates that 80 percent of diabetes deaths occur in low- and middleincome countries and projects that such deaths will double between 2005 and 2030 [6].

Species of Passiflora are commonly found all over the world. Studies have revealed its use in anti-inflammatory, antimicrobial, antioxidant, and anti tumor process. Various types of preparations, extracts, and individual compounds derived from this species have been found to possess a broad spectrum of pharmacological effects on several organs such as the brain, blood, and cardiovascular and nervous systems as well as on different biochemical processes and physiological functions including proteosynthesis, work capacity, reproduction, and sexual function. Studies are needed to examine the potential use of species of Passiflora extract in the prevention of pathologies, such as cardiac ischemia, renal ischemia, and neurodegenerative diseases and diabetes, where oxidative stress damage to protein seems to play a major role.

Medicinally, the fruit has been used in Amazonia as a preventative for yellow fever, gallstones, rabies, and ulcers. That region also prescribes a leaf decoction for preventing malaria and other fevers and for easing stomach upsets. Passion fruit is proved to have analgesic (pain-reliever), antianxiety, anti-inflammatory, antispasmodic, cough suppressant, aphrodisiac, central nervous system depressant, diuretic, hypotensive (lowers blood pressure), and sedative activities. Besides, it is traditionally reported to possess anticonvulsant, antidepressant, astringent, cardiotonic (tones, balances, and strengthens the heart), disinfectant, nervine (balances/calms nerves), neurasthenic (reduces nerve pain), tranquilizer, and vermifuge (expels worms) activities. It may have promising and powerful effects on neurological disorders and chronic diseases such as heart disease and cancer [7]. So far, no study has been carried out to reveal the antihyperglycemic effect of $P$. ligularis. This study was undertaken to find out antioxidant and antidiabetic potential in aqueous fruit extract of P. ligularis.

\section{Materials and Methods}

2.1. Collection and Extraction of Plant Material. Fresh fruits of Passiflora ligularis were collected from Munnar, Kerala, and authenticated by Dr. G. V. S. Murthy Botanical survey of India, Tamil Nadu Agricultural University, Coimbatore (Voucher number BSI/SRC/5/23/2012/Tech/495). The fruits were washed thoroughly with water and the peel was removed; then the pulp was collected. The fruit pulp was then grounded in an electric mixer. The fruit juice was collected and filtered. The aqueous extract was concentrated using a rotary evaporator at room temperature for 3 days to obtain a dark brown pigment and weighed. Then the aqueous extract was stored in an air tight container for future use.

2.2. Preliminary Phytochemical Screening. Phytochemical screening was done for analyzing the presence of secondary metabolites that are responsible for curing ailments $[8,9]$.
2.3. Experimental Animals. Adult male albino rats weighing about $150-200 \mathrm{~g}$ were obtained from the animal house of Karpagam University, Coimbatore, and used for the study. Rats were housed at constant temperature of $22 \pm 5^{\circ} \mathrm{C}$ with a 12-hour light, 12-hour dark cycle, and fed on pellets with free access to tap water. All the experiments were carried out according to the guidelines recommended by the Committee for the Purpose of Control and Supervision of Experiments on Animals (CPCSEA), Government of India.

2.4. Acute Toxicity. The Wistar albino rats weighing between 150 and $180 \mathrm{~g}$ were used for the study. 250, 500, 1000, and $2000 \mathrm{mg} / \mathrm{kg}$ of the aqueous extract of Passiflora ligularis were administered orally to four groups of five animals each. Another group of five rats served as control and this received $1 \mathrm{ml}$ of physiological saline. They were all placed under observation for 24 hours for the signs of lethality, toxic symptoms, behavioral changes, or deaths.

2.5. Induction of Diabetes. Diabetes was induced by a single intraperitoneal injection of streptozotocin $(30 \mathrm{mg} / \mathrm{kg})$ in water. Hyperglycemia was confirmed after $72 \mathrm{hrs}$ by the elevated blood glucose and the behavioral changes (excess thirst and frequent urination). The rats with blood glucose level more than $240 \mathrm{mg} / \mathrm{dL}$ were used for the study.

\section{Glucose Tolerance Test [10]}

3.1. Experimental Design for GTT of Diabetic Rats. The glucose tolerance test was studied in the aqueous extract of Passiflora ligularis on diabetic rats. The animals were divided into 5 groups $(n=3)$ as follows:

Group 1: Control rats;

Group 2: Diabetic control rats;

Group 3: Rats treated with $200 \mathrm{mg} / \mathrm{kg}$ of aqueous extract of fruit of $P$. ligularis;

Group 4: Rats treated with $400 \mathrm{mg} / \mathrm{kg}$ of aqueous extract of fruit of $P$. ligularis;

Group 5: Rats treated with $600 \mathrm{mg} / \mathrm{kg}$ of aqueous extract of fruit of $P$. ligularis.

The animals were fasted overnight with free access to water. Fasting blood sample was drawn from the tail and blood glucose level was measured by using heamoglucostrips in glucometer (Life scan, Johnson and Johnson Ltd.) and it was also confirmed by O-Toluidine method. For GTT, control and diabetic control rats were given water only. Group 3, 4, 5 rats were treated with their corresponding concentration 200, 400 , and $600 \mathrm{mg} / \mathrm{kg}$ of aqueous fruit extract of P. ligularis, respectively. The blood glucose level was checked after 30 minutes. Then all the rats were loaded with $3 \mathrm{~g} / \mathrm{kg}$ glucose solution. Three more blood samples were collected at 60, 120, and 180 minutes after the glucose load.

Glycemic index was calculated by using formula

$$
\text { Glycemic index }=\frac{\text { Initial }- \text { Final }}{\text { Initial }} \times 100 \text {. }
$$


TABLE 1: Phytochemical screening aqueous fruit extract of Passiflora ligularis.

\begin{tabular}{|c|c|c|c|c|c|c|c|c|c|c|}
\hline Extracts & $\mathrm{AL}$ & SA & TP & FL & ST & CG & $\mathrm{OF}$ & TN & AP & $\mathrm{CHO}$ \\
\hline Aqueous & ++ & ++ & + & ++ & ++ & ++ & ++ & + & + & + \\
\hline
\end{tabular}

AL: alkaloids; CHO: carbohydrates; ST: steroids; CG: cardioglycosides; FL: flavanoids; SA: saponins; TP: tannin and phenolic compounds; OF: oils and fats; AP: amino acids and proteins; TN: terpenoids.

“+": present; "-" absent.

3.2. Antidiabetic Study. The animals were divided into five groups with four rats in each group. Group 1 served as control, normal healthy rats given normal pelleted diet and $1.0 \mathrm{ml}$ citrate buffer as vehicle, group 2 rats were induced with diabetes by a single intraperitoneal injection of $30 \mathrm{mg} / \mathrm{kg} \mathrm{bw}$ of streptozotocin and kept without any treatment for 30 days, group 3 rats were induced with diabetes as mentioned in group 2 and treated with glibenclamide $(1.25 \mathrm{mg} / \mathrm{kg} \mathrm{bw})$ orally through oral intragastric tube, for a period of 30 days, group 4 rats were induced with diabetes as mentioned in group 2 and treated with Passiflora ligularis $(400 \mathrm{mg} / \mathrm{kg} \mathrm{bw}$ ) orally for a period of 30 days, group 5 rats were treated with Passiflora ligularis alone ( $400 \mathrm{mg} / \mathrm{kg} \mathrm{bw}$ ) orally for a period of 30 days, and the fruit aqueous extract $(400 \mathrm{mg} / \mathrm{kg}$ ) was given orally through intragastric tube for 30 days.

The extract was administered orally by intragastric tubes for the study period of 30 days and then they were sacrificed under mild chloroform anesthesia. The blood and the serum separated from blood were used for biochemical studies. The organs liver, kidney, and pancreas were collected in saline and used for antioxidant analysis.

3.3. Biochemical Analysis. Serum glucose was estimated by kit method [11]. Hemoglobin and glycosylated hemoglobin was estimated by Drabkin's method [12]. Serum cholesterol and HDL was estimated by one step method [13] using diagnostic reagent kit manufactured by Span Diagnostics Ltd. Triglycerides were estimated by GPO-PAP, end point assay [14] using diagnostic reagent kit manufactured by Span Diagnostics Ltd. The activities of serum aspartate aminotransferase (AST) and alanine aminotransferase (ALT) were estimated by using commercially available kits [15]. The activities of serum alkaline phosphatase were also estimated [16]. Total protein and albumin in the serum were estimated by Biuret method [17]. Urea in the serum was estimated by using the diagnostic kit based on the DAM method [18]; creatinine in serum was estimated by using the diagnostic kit based on the alkaline picrate method [19]. Bilirubin in serum was estimated by using the Span Diagnostic kit [20].

3.4. Antioxidant Analysis in Tissues. In the present study, antioxidant activity of aqueous fruit extract of Passiflora ligularis was analyzed in different organs, namely, liver, kidney, and pancreas. After 30 days the rats were sacrificed under mild chloroform anesthesia and the organs were collected in saline liver which was used for the estimation of glycogen [21]. All the tissues were used for estimation of protein [22], enzymic antioxidants such as superoxide dismutase [23], catalase [24], GPx [25], and nonenzymatic antioxidants such as vitamin C [26], vitamin E [27], and reduced glutathione [28]. The lipid peroxidation [29] was also estimated.

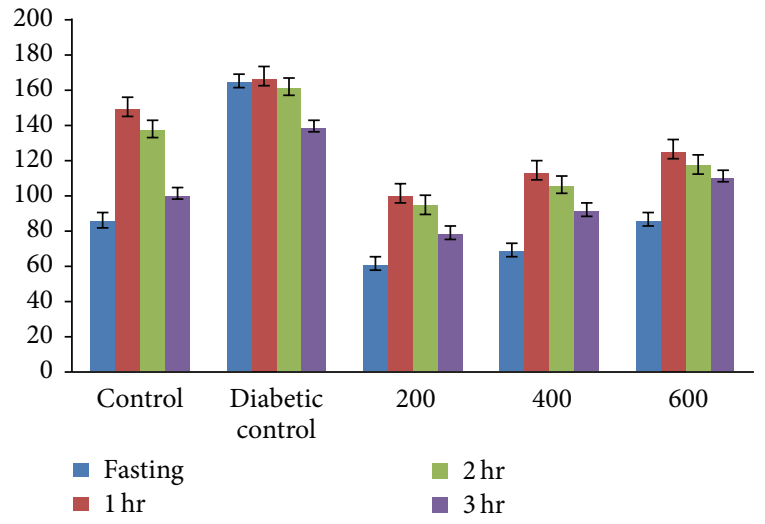

Figure 1: Oral glucose tolerance test of aqueous extract of Passiflora ligularis in experimental rats.

3.5. Statistical Analysis. The results obtained were expressed as mean \pm standard deviation (SD). The statistical comparison among the groups was performed with one-way analysis of variance followed by Duncan's Multiple Range Test (DMRT) using SPSS version 10 (SPSS, Chicago, IL). The limit of statistical significance was set at $P<0.05$.

\section{Results and Discussion}

Phytochemicals play an important role in plant defense against prey, microorganism, and stress as well as interspecies protections. These plant components have been used as drugs for millennia. Hence, phytochemical screening serves as the initial step in predicting the types of potential active compounds from plants [30]. Table 1 shows the phytochemicals present in aqueous fruit extract of $P$. ligularis.

Phytochemical screening of $P$. ligularis revealed the presence of various phytochemicals (Table 1). In particular the aqueous extract of Passiflora ligularis revealed the presence of alkaloids, tannins, phenolic compounds, flavonoids, steroids, cardiac glycosides, terpenoids, and carbohydrates.

In acute toxicity study, the experimental rats had slept several hours, after administration of Passiflora ligularis extract to the Wistar albino rats when compared to normal control rats. But there were no gross behavioral changes or morphological changes like respiratory distress, hair loss, restlessness, convulsions, laxative, coma, weight loss, urination, itching, and so forth. There was no lethality and no toxic reaction was found at any of the doses selected till the end of the treatment. This indicates the safety nature of Passiflora ligularis extract on Wistar albino rats.

Figure 1 shows the blood glucose levels in GTT of control and experimental groups of rats after oral administration 
TABle 2: Effect of P. ligularis on glucose, hemoglobin, glycosylated hemoglobin, and lipid profile in serum of control and experimental rats.

\begin{tabular}{|c|c|c|c|c|c|c|}
\hline Parameters & Glucose (mg/dL) & $\begin{array}{c}\text { Hemoglobin } \\
(\mathrm{mg} / \mathrm{dL})\end{array}$ & $\begin{array}{c}\text { Glycosylated } \\
\text { hemoglobin (\%) }\end{array}$ & $\begin{array}{c}\text { Total cholesterol } \\
(\mathrm{mg} / \mathrm{dL})\end{array}$ & $\begin{array}{c}\text { Triglycerides } \\
(\mathrm{mg} / \mathrm{dL})\end{array}$ & $\mathrm{HDL}(\mathrm{mg} / \mathrm{dL})$ \\
\hline $\begin{array}{l}\text { Control } \\
\text { (Group I) }\end{array}$ & $96.1 \pm 0.28^{\mathrm{a}}$ & $13.3 \pm 0.43^{\mathrm{a}}$ & $6.5 \pm 0.12^{\mathrm{a}}$ & $111.6 \pm 5.77^{\mathrm{a}}$ & $77.4 \pm 0.40^{\mathrm{a}}$ & $21.3 \pm 0.28^{\mathrm{a}}$ \\
\hline $\begin{array}{l}\text { Diabetic control } \\
\text { (Group II) }\end{array}$ & $221.6 \pm 2.28^{b}$ & $6.8 \pm 0.05^{\mathrm{b}}$ & $11.2 \pm 0.01^{\mathrm{b}}$ & $228.3 \pm 2.88^{\mathrm{b}}$ & $188.5 \pm 0.46^{\mathrm{b}}$ & $15.2 \pm 0.21^{\mathrm{b}}$ \\
\hline $\begin{array}{l}\text { Diabetes + } \\
\text { glibenclamide } \\
\text { (Group III) }\end{array}$ & $111.6 \pm 0.57^{\mathrm{c}}$ & $13.3 \pm 0.04^{\mathrm{a}}$ & $5.4 \pm 0.04^{\mathrm{c}}$ & $115.6 \pm 1.15^{\mathrm{a}}$ & $101.6 \pm 2.88^{\mathrm{c}}$ & $23.0 \pm 0.04^{\mathrm{c}}$ \\
\hline $\begin{array}{l}\text { Diabetes }+P . \\
\text { ligularis extract } \\
\text { (Group IV) }\end{array}$ & $116.1 \pm 0.28^{\mathrm{d}}$ & $12.7 \pm 0.12^{\mathrm{c}}$ & $6.3 \pm 0.05^{\mathrm{d}}$ & $131.6 \pm 2.88^{\mathrm{c}}$ & $88.8 \pm 0.11^{\mathrm{d}}$ & $25.1 \pm 0.28^{\mathrm{d}}$ \\
\hline $\begin{array}{l}\text { P. ligularis extract } \\
\text { treated alone } \\
(\text { Group V) }\end{array}$ & $95.1 \pm 0.28^{\mathrm{a}}$ & $13.4 \pm 0.01^{\mathrm{a}}$ & $6.6 \pm 0.02^{\mathrm{a}}$ & $101.6 \pm 2.88^{\mathrm{d}}$ & $78.8 \pm 0.28^{\mathrm{a}}$ & $21.3 \pm 0.28^{\mathrm{a}}$ \\
\hline
\end{tabular}

Values are expressed as mean \pm SD for four animals in each group.

Values not sharing common superscript letters $(\mathrm{a}-\mathrm{d})$ differ significantly at $P<0.05$ (DMRT).

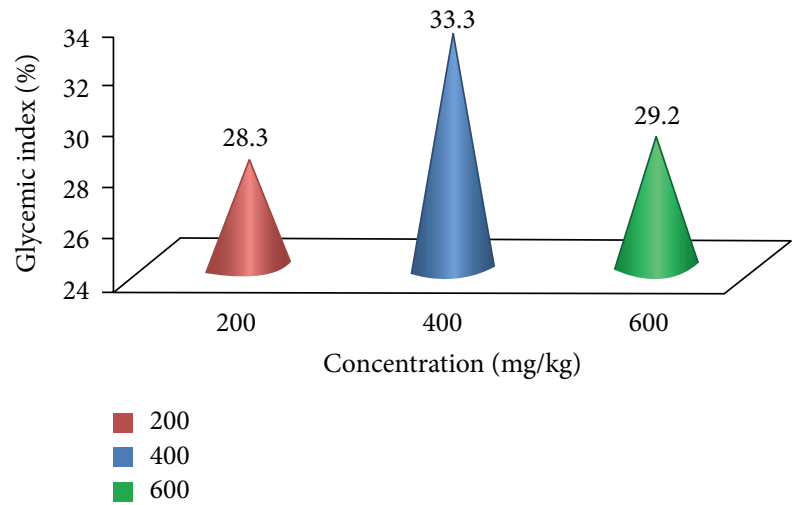

Figure 2: The glycemic index of aqueous extract of Passiflora ligularis.

of glucose. The aqueous fruit extract of Passiflora ligularis was administered orally $(200,400$, and $600 \mathrm{mg} / \mathrm{kg}$, for 15 days) to experimental animals. In diabetic rats, the peak increase in blood glucose concentration was observed after $60 \mathrm{~min}$ and it remained high over $120 \mathrm{~min}$. Passiflora ligularis treated diabetic rats showed significant decrease in blood glucose concentration at $60 \mathrm{~min}$ and at $120 \mathrm{~min}$ interval and the glycemic index was found to be $28.3 \%, 33.3 \%, 29.2 \%$, respectively (Figure 2). Among the various doses (200, 400, and $600 \mathrm{mg} / \mathrm{kg}$ ) of $P$. ligularis on OGTT in normal and diabetic rats, $400 \mathrm{mg} / \mathrm{kg}$ brought an effective hypoglycemic effect when compared to other doses. This effect may occur due to reduction in intestinal glucose absorption or induction of glycogenic process along with reduction in glycogenolysis and glyconeogenesis. Therefore, this effective dosage, $400 \mathrm{mg} / \mathrm{kg}$ of aqueous fruit extract of $P$. ligularis, was used for further antidiabetic studies in Wistar albino rats. The observed diabetic untreated rats were increased in serum glucose in due to the effect of STZ which cause tissue damage in pancreas that destroy $\beta$ cells and result in insulin deficiency. Insulin deficiency ultimately causes increased blood glucose [31].
In diabetic control rats, there is significant elevation of glucose. Streptozotocin causes selective destruction of cells of islets of pancreas and brings an increase in blood glucose levels [32]. It is evident from the present investigation that administration at the dose of $30 \mathrm{mg} / \mathrm{kg}$ body weight causes significant diabetogenic response in albino rats. From these results given in Table 2, that reduction in blood glucose levels brought by aqueous extract of $P$. ligularis was quite comparable with reduction brought about by glibenclamide. A significant elevation in hemoglobin and increase in glycosylated hemoglobin noticed in diabetic rats were normalized to near normal with the administration of aqueous fruit extract of $P$. ligularis and glibenclamide. Reduction in hemoglobin in diabetic rats is due to the interaction of excess glucose with hemoglobin to form glycosylated hemoglobin (Table 2). Glycosylated hemoglobin (HbAlc) was almost doubled in STZ rats and it decreased significantly when treated with $P$. ligularis and maintains the hemoglobin and glycosylated hemoglobin in their normal range. This proves the role of $P$. ligularis in controlling the blood glucose.

A significant elevation in serum lipids was observed in diabetic rats when compared with control rats (Table 2). In case of insulin deficiency as in diabetes mellitus, lipolysis is not inhibited and therefore this leads to hyperlipidemia. On oral administration of Passiflora ligularis fruit extract to diabetic rats for 30 days significantly reversed these values to near normal. This may be due to the increase in insulin secretion by Passiflora ligularis which decreases the total cholesterol and total triglycerides and increases HDL level.

Table 3 shows the level of hepatic and renal markers; the levels of urea, creatinine, and bilirubin were significantly increased in diabetic group and treatment with Passiflora ligularis extract for 30 days significantly reversed these values to near normal. Similar effect was observed in glibenclamide treated group. Passiflora ligularis extract alone treated rats showed similar effect to that of control rats. The AST and ALP are considered sensitive indicator of liver injury [33]. Rise in serum level of AST and ALP have been attributed to the damaged structural integrity of the liver. The significant 
TABLE 3: Effect of P. ligularis on kidney and liver markers, total protein, albumin, and globulin in serum of control and experimental rats.

\begin{tabular}{|c|c|c|c|c|c|c|c|c|}
\hline Parameters & Urea (mg/dL) & $\begin{array}{c}\text { Creatinine } \\
(\mathrm{mg} / \mathrm{dL})\end{array}$ & $\begin{array}{c}\text { Bilirubin } \\
(\mathrm{mg} / \mathrm{dL})\end{array}$ & SGOT (IU/L) & SGPT (IU/L) & $\begin{array}{c}\text { Total protein } \\
(\mathrm{mg} / \mathrm{dL})\end{array}$ & $\begin{array}{c}\text { Albumin } \\
(\mathrm{mg} / \mathrm{dL})\end{array}$ & $\begin{array}{l}\text { Globulin } \\
(\mathrm{mg} / \mathrm{dL})\end{array}$ \\
\hline $\begin{array}{l}\text { Control } \\
\text { (Group I) }\end{array}$ & $27.9 \pm 0.01^{\mathrm{a}}$ & $0.5 \pm 0.06^{\mathrm{a}}$ & $1.10 \pm 0.01^{\mathrm{a}}$ & $33.3 \pm 0.28^{\mathrm{a}}$ & $27.4 \pm 0.40^{\mathrm{a}}$ & $8.2 \pm 0.23^{\mathrm{a}}$ & $5.5 \pm 0.11^{\mathrm{a}}$ & $2.4 \pm 0.67^{\mathrm{a}}$ \\
\hline $\begin{array}{l}\text { Diabetic control } \\
\text { (Group II) }\end{array}$ & $30.4 \pm 0.46^{\mathrm{b}}$ & $0.7 \pm 0.04^{\mathrm{b}}$ & $1.33 \pm 0.02^{\mathrm{b}}$ & $56.1 \pm 0.98^{b}$ & $59.0 \pm 0.80^{\mathrm{b}}$ & $4.6 \pm 0.02^{\mathrm{b}}$ & $3.3 \pm 0.02^{\mathrm{b}}$ & $0.6 \pm 0.01^{\mathrm{b}}$ \\
\hline $\begin{array}{l}\text { Diabetes + } \\
\text { glibenclamide } \\
\text { (Group III) }\end{array}$ & $25.4 \pm 0.34^{\mathrm{c}}$ & $0.5 \pm 0.01^{\mathrm{a}}$ & $1.18 \pm 0.01^{\mathrm{c}}$ & $38.4 \pm 0.40^{c}$ & $33.3 \pm 0.23^{\mathrm{c}}$ & $7.7 \pm 0.03^{c}$ & $4.8 \pm 0.26^{\mathrm{c}}$ & $2.9 \pm 0.05^{\mathrm{c}}$ \\
\hline $\begin{array}{l}\text { Diabetes }+P . \\
\text { ligularis extract } \\
\text { (Group IV) }\end{array}$ & $23.2 \pm 0.35^{\mathrm{d}}$ & $0.4 \pm 0.01^{\mathrm{c}}$ & $1.15 \pm 0.01^{\mathrm{d}}$ & $43.3 \pm 0.28^{\mathrm{d}}$ & $41.0 \pm 0.86^{\mathrm{d}}$ & $7.2 \pm 0.08^{d}$ & $4.7 \pm 0.19^{c}$ & $2.3 \pm 0.06^{\mathrm{a}}$ \\
\hline $\begin{array}{l}\text { P. ligularis extract } \\
\text { treated alone } \\
(\text { Group V) }\end{array}$ & $27.6 \pm 0.34^{\mathrm{a}}$ & $0.6 \pm 0.01^{\mathrm{d}}$ & $1.09 \pm 0.01^{\mathrm{a}}$ & $35.1 \pm 0.28^{\mathrm{e}}$ & $29.3 \pm 0.28^{\mathrm{e}}$ & $8.6 \pm 0.05^{\mathrm{e}}$ & $5.4 \pm 0.10^{\mathrm{a}}$ & $3.1 \pm 0.01^{\mathrm{d}}$ \\
\hline
\end{tabular}

Values are expressed as mean \pm SD for four animals in each group.

Values not sharing common superscript letters (a-d) differ significantly at $P<0.05$ (DMRT)

TABLE 4: Changes on protein levels in liver, kidney, and pancreas of control and experimental animals.

\begin{tabular}{lccc}
\hline Particulars & Liver & $\begin{array}{c}\text { Protein }(\mathrm{mg} / \mathrm{g}) \\
\text { Kidney }\end{array}$ & Pancreas \\
\hline $\begin{array}{l}\text { Control } \\
\text { (Group I) }\end{array}$ & $1.42 \pm 0.07^{\mathrm{a}}$ & $1.06 \pm 0.03^{\mathrm{a}}$ & $0.93 \pm 0.03^{\mathrm{a}}$ \\
$\begin{array}{l}\text { Diabetic control } \\
\text { (Group II) }\end{array}$ & $0.87 \pm 0.01^{\mathrm{b}}$ & $0.57 \pm 0.06^{\mathrm{b}}$ & $0.50 \pm 0.12^{\mathrm{b}}$ \\
$\begin{array}{l}\text { Diabetic + } \\
\text { glibenclamide } \\
\text { (Group III) }\end{array}$ & $1.26 \pm 0.04^{\mathrm{c}}$ & $0.88 \pm 0.06^{\mathrm{c}}$ & $0.80 \pm 0.09^{\mathrm{c}}$ \\
$\begin{array}{l}\text { Diabetic }+ \\
\text { Passiflora ligularis }\end{array}$ & $1.34 \pm 0.025^{\mathrm{cd}}$ & $1.01 \pm 0.06^{\mathrm{ad}}$ & $0.91 \pm 0.03^{\mathrm{a}}$ \\
$\begin{array}{l}\text { Group IV } \\
\text { Passiflora ligularis } \\
\text { alone treated } \\
\text { (Group V) }\end{array}$ & $1.48 \pm 0.16^{\mathrm{ad}}$ & $1.08 \pm 0.06^{\mathrm{a}}$ & $1.07 \pm 0.17^{\mathrm{d}}$ \\
\hline
\end{tabular}

Values are expressed as mean \pm SD for four animals in each group.

Values not sharing common superscript letters $(a-d)$ differ significantly at $P<0.05$ (DMRT).

decrease in liver enzymes, namely, AST and ALP levels, was noticed after oral administration of aqueous extract of $P$. ligularis as compared to diabetic animals. It implies the normal functioning and protective effect of $P$. ligularis liver and supports hepatoprotective nature of $P$. ligularis.

The results from Table 3 show that the serum total protein level in diabetic control rats was significantly reduced. Increase in serum protein, that is, the ratio of albumin and globulin in diabetic rats treated with aqueous extract of $P$. ligularis and standard drug, was observed. Liver damage is most common in diabetes mellitus. Administration of Passiflora ligularis fruit extract decreased the level of liver markers in diabetic treated rats. This shows the hepatoprotective effect of $P$. ligularis.

STZ causes damage to liver, kidney, and pancreas as well as the hyperglycemia related changes which may persist in the tissues. The changes on protein levels in tissues such as liver, kidney, and pancreas of the experimental animals are given in Table 4 . The level of protein in liver and kidney

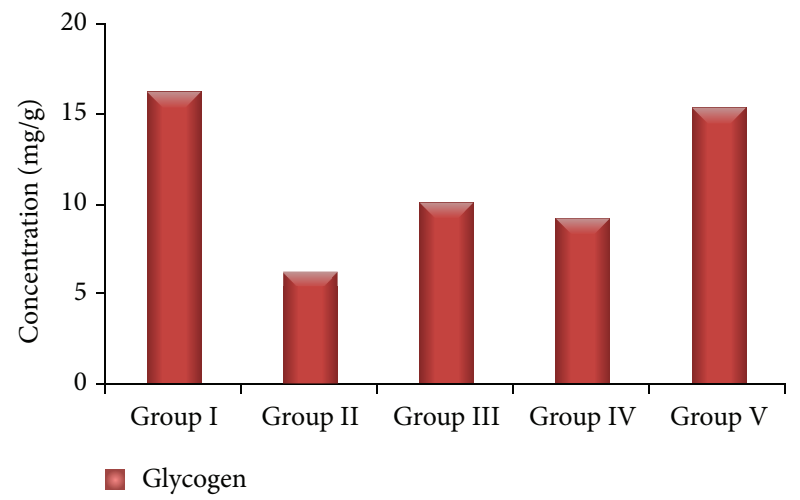

FIGURE 3: Changes on liver glycogen of control and experimental rats.

was decreased in diabetic group on comparison with control group. On treatment with aqueous fruit extract of Passiflora ligularis and standard drug glibenclamide to diabetic rats for 30 days the values were significantly increased to near normal. Aqueous extract of Passiflora ligularis alone treated group did not show any adverse changes. The reduction of the level of total proteins in induced rats was attributed to localized damage in the endoplasmic reticulum which results in the loss of $\mathrm{P}_{450}$ leading to its functional failure with a decrease in protein synthesis. The rise in protein levels in the treated groups suggests the stabilization of endoplasmic reticulum leading to protein synthesis [34]. Administration of Passiflora ligularis may enhance the protein synthesis by stabilizing the endoplasmic reticulum.

In this study, the liver glycogen level was decreased significantly in Group II diabetic rats, compared to glibenclamide as standard and Passiflora ligularis treated groups. Liver glycogen content was significantly reduced in STZ induced diabetic rats (Figure 3). Glycogen is the primary intracellular storage form of glucose and its levels in various tissues are a direct reflection of insulin activity as insulin promotes intracellular glycogen deposition by stimulating glycogen 


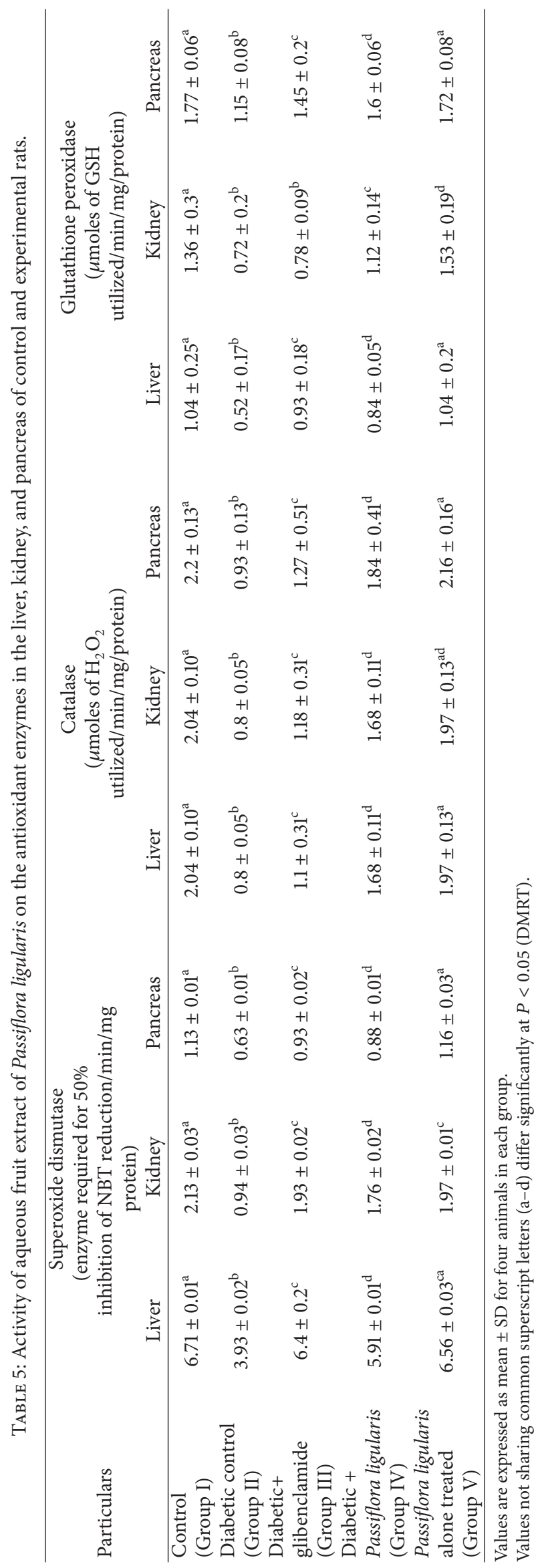




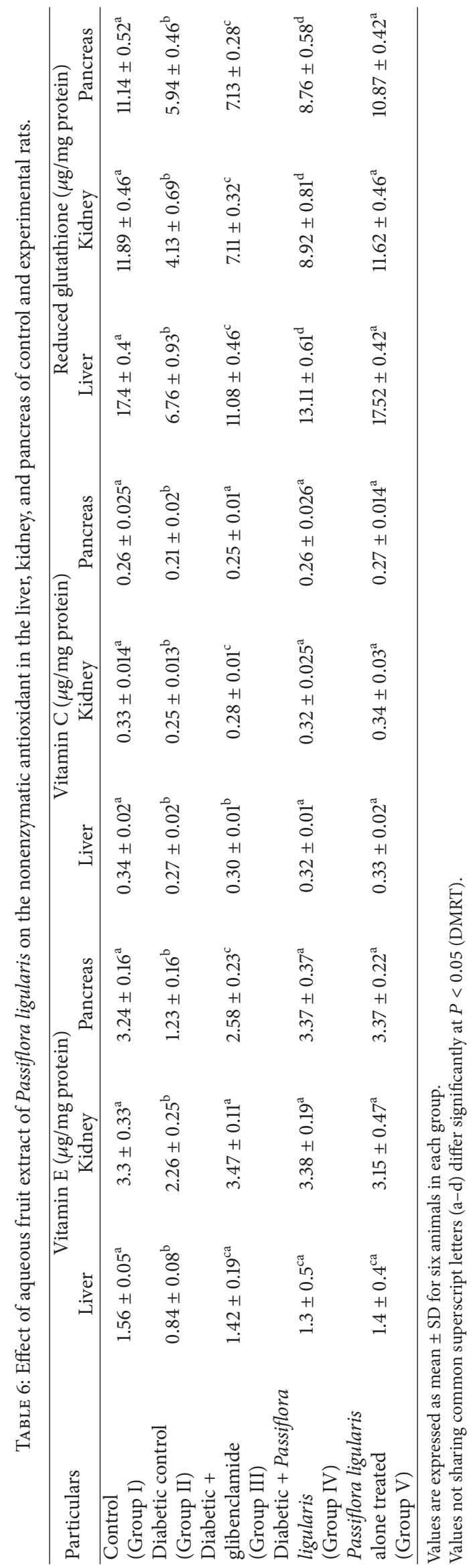


synthase and inhibiting glycogen phosphorylase [35]. The significant increase of liver glycogen level in the extract-treated diabetic groups may be due to reactivation of the glycogen synthase system. The experimental results indicate that the aqueous fruit extract of Passiflora ligularis has considerable antidiabetic activity and is capable of maintaining the liver glycogen level.

Table 5 demonstrates the results of the antioxidants enzymes levels of SOD, catalase, and GPX in experimental rats. These enzymatic antioxidants are significantly decreased in different organs (liver, kidney, and pancreas) due to the inadequacy of the antioxidant defences in combating ROS mediated damage and when they are treated with aqueous fruit extract of Passiflora ligularis the activity of these enzymes was increased and may help to control the free radicals when compared to diabetic rats and the effect produced by aqueous fruit extract of Passiflora ligularis was comparable with that of standard drug glibenclamide. Implication of oxidative stress in the pathogenesis of diabetes is suggested, not only by oxygen free-radical generation, but also due to nonenzymatic protein glycosylation, autooxidation of glucose, impaired glutathione metabolism, alteration in antioxidant enzymes, lipid peroxides formation, and decreased ascorbic acid levels. In addition to GSH, there are other defense mechanisms against free radicals like the enzymes superoxide dismutase (SOD), reduced glutathione (GSH), and catalase (CAT) whose activities contribute to eliminate superoxide, hydrogen peroxide, and hydroxyl radicals [36]. The decreased activities of CAT and SOD in diabetic rats may be a response to increased production of $\mathrm{H}_{2} \mathrm{O}_{2}$ and $\mathrm{O}_{2}$ by the autoxidation of glucose. These enzymes play an important role in maintaining physiological levels of oxygen and hydrogen peroxide by hastening the dismutation of oxygen radicals and eliminating organic peroxides and hydroperoxides generated from inadvertent exposure to STZ [37]. The observed increases in the antioxidant enzymes in diabetic treated rats are due to the presence of secondary metabolites in the aqueous fruit extract of Passiflora ligularis. The aqueous fruit extract Passiflora ligularis is rich in flavonoid content which provide to have good antioxidant potential and it is able to reverse the changes in diabetic control rats.

Table 6 indicates a significant reduction in the nonenzymatic antioxidants like glutathione (GSH) vitamins $\mathrm{C}$ and $\mathrm{E}$ in diabetic rats when compared with control rats. The levels of these antioxidants were significantly increased in different organs (liver, kidney, and pancreas) of diabetic rats by treating with aqueous fruit extract of Passiflora ligularis. GSH has a multifaceted role in antioxidant defense. It is a direct scavenger of free radicals as well as a cosubstrate for peroxide detoxification by glutathione peroxidases. Oxidative stress in diabetes decreased the level of GSH in different organs of rat when compared to control. Oral administration of aqueous fruit extract of Passiflora ligularis for 30 days showed significant elevation in all the nonenzymatic antioxidants values and reached near normal values. This indicates that administration of aqueous fruit extract of Passiflora ligularis can reduce the oxidative stress leading to less degradation of GSH due to less production of ROS in diabetic stage.
TABLE 7: Changes on lipid peroxidation in liver, kidney, and pancreas of control and experimental rats.

\begin{tabular}{|c|c|c|c|}
\hline \multirow{2}{*}{ Particulars } & \multicolumn{3}{|c|}{ Lipid peroxidation* } \\
\hline & Liver & Kidney & Pancreas \\
\hline $\begin{array}{l}\text { Control } \\
\text { (Group I) }\end{array}$ & $14.9 \pm 0.26^{\mathrm{a}}$ & $9.8 \pm 0.2^{\mathrm{a}}$ & $9.07 \pm 0.14^{\mathrm{a}}$ \\
\hline $\begin{array}{l}\text { Diabetic control } \\
\text { (Group II) }\end{array}$ & $31.1 \pm 0.32^{\mathrm{b}}$ & $16.2 \pm 0.18^{\mathrm{b}}$ & $12.6 \pm 0.34^{\mathrm{b}}$ \\
\hline $\begin{array}{l}\text { Diabetic + } \\
\text { glibenclamide } \\
\text { (Group III) }\end{array}$ & $18.8 \pm 0.23^{\mathrm{c}}$ & $12.4 \pm 0.53^{\mathrm{c}}$ & $10.19 \pm 0.11^{c}$ \\
\hline $\begin{array}{l}\text { Diabetic }+ \\
\text { Passiflora ligularis } \\
\text { (Group IV) }\end{array}$ & $16.9 \pm 0.18^{\mathrm{d}}$ & $13.5 \pm 0.35^{\mathrm{d}}$ & $9.69 \pm 0.13^{d}$ \\
\hline $\begin{array}{l}\text { Passiflora ligularis } \\
\text { alone treated } \\
\text { (Group V) }\end{array}$ & $15.4 \pm 0.16^{\mathrm{a}}$ & $9.5 \pm 0.21^{\mathrm{a}}$ & $9.10 \pm 0.49^{\mathrm{a}}$ \\
\hline
\end{tabular}

Values are expressed as mean \pm SD for six animals in each group.

Values not sharing common superscript letters (a-d) differ significantly at $P<0.05$ (DMRT).

${ }^{*} n$ moles of MDA formed/min/mg of protein.

Significant elevation of GSH level was reported in the $P$. corymbosa (Rottl.) root extract-treated diabetic rats [38].

Table 7 explains a significant reduction in the lipid peroxidation in liver, kidney, and pancreas of control and experimental animals. In liver, kidney, and pancreas tissues of diabetic rats, lipid peroxidation (LPO) levels were elevated significantly as compared to that of control rats. Hydroxyl radicals are the major active species that cause lipid oxidation and significant biological damage [39]. The ability of the Passiflora ligularis extracts to quench hydroxyl radicals seems to be directly related to inhibiting the process of lipid peroxidation. After oral administration of Passiflora ligularis extract for 30 days the elevated values restore back to near normal level. Both of the treated groups showed significant decrease in lipid peroxidation, suggesting its role in protection against lipid peroxidation.

\section{Conclusion}

In conclusion, the result of this study shows that oral administration of the aqueous extract of $P$. ligularis reduces blood glucose, serum lipids which could be due to improvement in insulin secretion by recovery of pancreatic $\beta$ cells. P. ligularis possesses antioxidant potential which may be used for therapeutic purposes mainly in the prevention of oxidative damage that occurs during diabetes. Presence of alkaloids and flavonoids of $P$. ligularis has also been found to be beneficial in controlling diabetes and many other diseases as evident from this study. Therefore, it is concluded that the aqueous extract of $P$. ligularis possesses antidiabetic activity and it may prove to be effective for the management of diabetes.

\section{Conflict of Interests}

The authors declare that there is no conflict of interests regarding the publication of this paper. 


\section{Acknowledgments}

The authors are thankful to their Chancellor, CEO, Vice Chancellor, and Registrar of Karpagam University for providing facilities and encouragement.

\section{References}

[1] J. Gotep, "Glycosides fraction extracted from fruit pulp of Cucumis metuliferus E. Meyer has antihyperglycemic effect in rats with alloxan-induced diabetes," Journal of Natural Pharmaceuticals, vol. 2, no. 2, pp. 48-51, 2011.

[2] V. K. Sharma, S. Kumar, H. J. Patel, and S. Hugar, "Hypoglycemic activity of Ficus Glomerata in alloxan induced diabetic rats," International Journal of Pharmaceutical Sciences Review and Research, vol. 1, no. 2, pp. 18-22, 2010.

[3] K. C. Copeland, P. Zeitler, M. Geffner et al., "TODAY Study Group. Characteristics of adolescents and youth with recentonset type 2 diabetes: The TODAY cohort at baseline," Journal of Clinical Endocrinology and Metabolism, vol. 96, no. 1, pp. 159167, 2011.

[4] International Diabetes Federation (IDF), Diabetes Atlas, International Diabetes Federation (IDF), Brussels, Belgium, 4th edition, 2009.

[5] A. Ghamarian, M. Abdollahi, X. Su, A. Amiri, A. Ahadi, and A. Nowrouzi, "Effect of chicory seed extract on glucose tolerance test (GTT) and metabolic profile in early and late stage diabetic rats," DARU Journal of Pharmaceutical Sciences, vol. 20, no. 1, article 56, 2012.

[6] K. P. S. Kumar, D. Bhowmik, S. Srivastava, S. Paswan, and A. Dutta, "Diabetes epidemic in India- a comprehensive review of clinical features, management and remedies," The Pharma Innovation, vol. 1, no. 2, p. 18, 2012.

[7] P. P. Joy, J. Thomas, S. Mathew, and B. P. Skaria, "Medicinal plants," in Tropical Horticulture, T. K. Bos, J. Kabir, P. Das, and P. P. Joy, Eds., vol. 2, pp. 449-632, Naya Prokash, Calcutta, India, 2010, Medicinal Plants,.

[8] G. E. Trease and W. C. Evans, Pharmacognosy, W. B. Saunders, Philadelphia, Pa, USA, 4th edition, 1996.

[9] J. B. Harborne, Phytochemical Methods, Chapman \& Hall, London, UK, 1987.

[10] S. Bonner-Weir, "Morphological evidence for pancreatic polarity of $\beta$-cell within islets of Langerhans," Diabetes, vol. 37, no. 5 , pp. 616-621, 1988.

[11] T. Sasaki, S. Matsy, and A. Sonae, "Effect of acetic acid concentration on colour reaction in O-Toluidine boric acid method for blood glucose estimation," Rinsho Kagaku, vol. 1, pp. 346-353, 1972.

[12] D. L. Drabkin and J. M. Austin, "Spectrophotometric constants for common hemoglobin derivatives in human, dog and rabbit blood," The Journal of Biological Chemistry, vol. 98, pp. 719-733, 1932.

[13] D. R. Wybenga, V. J. Pileggi, P. H. Dirstine, and J. di Giorgio, "Direct manual determination of serum total cholesterol with a single stable reagent," Clinical Chemistry, vol. 16, no. 12, pp. 980-984, 1970.

[14] G. Bucolo and H. David, "Quantitative determination of serum triglycerides by the use of enzymes," Clinical Chemistry, vol. 19, no. 5, pp. 476-482, 1973.

[15] S. Reitman and S. Frankel, "A colorimetric method for the determination of serum glutamic oxalacetic and glutamic pyruvic transaminases," The American Journal of Clinical Pathology, vol. 28, no. 1, pp. 56-63, 1957.

[16] P. R. Kind and E. J. King, "Estimation of plasma phosphatase by determination of hydrolysed phenol with amino-antipyrine," Journal of Clinical Pathology, vol. 7, no. 4, pp. 322-326, 1954.

[17] W. Q. Wolfson, C. Chon, E. Calvary, and F. Ichiba, "Studies in serum proteins. A rapid procedure for the estimation of total protein, true albumin, total globulin, alpha globulin, beta globulin and gamma globulin in $100 \mathrm{ml}$. of serum," American Journal of Clinical Pathology, vol. 18, no. 9, pp. 723-730, 1948.

[18] C. G. Coulambe and L. A. Favrean, "Quaternary ammonium compound toxicity in chicken," Clinical Chemistry, vol. 11, no. 17, p. 624, 1965.

[19] R. W. Bonses and H. H. Taussky, "On the colorimetric determination of Creatinine by the Jaffe reaction," The Journal of Biological Chemistry, vol. 158, pp. 581-591, 1945.

[20] H. T. Malloy and K. T. Evelyn, "The determination of bilirubin with the photoelectric colorimeter," The Journal of Biological Chemistry, vol. 119, p. 481, 1937.

[21] M. A. Morales, A. J. Jabbagy, and H. R. Terenizi, "Mutations affecting accumulation of glycogen," Neurospora News Letters, vol. 30, pp. 24-25, 1973.

[22] O. H. Lowry, N. J. Rosenbrough, A. L. Farr, and R. J. Randall, "Protein measurement with the Folin phenol reagent," The Journal of Biological Chemistry, vol. 193, no. 1, pp. 265-275, 1951.

[23] K. Das, L. Samanta, and G. B. N. Chainy, "A modified spectrophotometric assay of superoxide dismutase using nitrite formation by superoxide radicals," Indian Journal of Biochemistry and Biophysics, vol. 37, no. 3, pp. 201-204, 2000.

[24] A. K. Sinha, "Colorimetric assay of catalase," Analytical Biochemistry, vol. 47, no. 2, pp. 389-394, 1972.

[25] J. T. Rotruck, A. L. Pope, H. E. Ganther, A. B. Swanson, D. G. Hafeman, and W. G. Hoekstra, "Selenium: biochemical role as a component of glutathione peroxidase," Science, vol. 179, no. 4073, pp. 588-590, 1973.

[26] S. T. Omaye, T. P. Turbull, and H. C. Sauberchich, "Selected methods for determination of ascorbic acid in cells, tissues and fluids," Methods in Enzymology, vol. 6, pp. 3-11, 1979.

[27] H. R. Rosenberg, Chemistry and Physiology of the Vitamins, Interscience Publisers, New York, NY, USA, 1942.

[28] M. S. Moron, J. W. Depierre, and B. Mannervik, "Levels of glutathione, glutathione reductase and glutathione S-transferase activities in rat lung and liver," Biochimica et Biophysica Acta, vol. 582, no. 1, pp. 67-78, 1979.

[29] H. Ohkawa, N. Ohishi, and K. Yagi, "Assay for lipid peroxides in animal tissues by thiobarbituric acid reaction," Analytical Biochemistry, vol. 95, no. 2, pp. 351-358, 1979.

[30] Y. L. Chew, E. W. L. Chan, P. L. Tan, Y. Y. Lim, J. Stanslas, and J. K. Goh, "Assessment of phytochemical content, polyphenolic composition, antioxidant and antibacterial activities of Leguminosae medicinal plants in Peninsular Malaysia," BMC Complementary and Alternative Medicine, vol. 11, article 12, 2011.

[31] R. A. DeFronzo and D. Tripathy, "Skeletal muscle insulin resistance is the primary defect in type 2 diabetes," Diabetes care, vol. 32, no. 2, pp. S157-S163, 2009.

[32] C. I. Sajeeth, P. K. Manna, R. Manavalan, and C. I. Jolly, "Antidiabetic activity of a polyherbal formulation, Esf/ay/500 in streptozotocin indu ced diabetic male Albino rats: a research," International Journal of Drug Formulation \& Research, vol. 1, no. 1, pp. 311-322, 2010. 
[33] N. P. Yadav, A. Pal, K. Shanker et al., "Synergistic effect of silymarin and standardized extract of Phyllanthus amarus against $\mathrm{CCl}_{4}$-induced hepatotoxicity in Rattus norvegicus," Phytomedicine, vol. 15, no. 12, pp. 1053-1061, 2008.

[34] S. Naskar, A. Islam, U. K. Mazumder, P. Saha, P. K. Haldar, and M. Gupta, "In vitro and in vivo antioxidant potential of hydromethanolic extract of phoenix dactylifera fruits," Journal of Scientific Research, vol. 2, no. 1, pp. 144-157, 2010.

[35] P. Malini, G. Kanchana, and M. Rajadurai, "Antibiabetic efficacy of ellagic acid in streptozotocin-induced diabetes mellitus in albino wistar rats," Asian Journal of Pharmaceutical and Clinical Research, vol. 4, no. 3, pp. 124-128, 2011.

[36] V. A. Kangralkar, D. S. Patil, and R. M. Bandivadekar, "Oxidative stress and diabetes: a review," International Journal of Pharmaceutical Applications, vol. 1, no. 1, pp. 38-45, 2010.

[37] L. Pari and M. Latha, "Protective role of Scoparia dulcis plant extract on brain antioxidant status and lipidperoxidation in STZ diabetic male Wistar rats," BMC Complementary and Alternative Medicine, vol. 4, article 16, 2004.

[38] V. N. Shilpa, N. Rajasekaran, V. K. Gopalakrishnan, and K. Devaki, "In-vivo antioxidant activity of Premna corymbosa (Rottl.) against streptozotocin induced oxidative stress in Wistar albino rats," Journal of Applied Pharmaceutical Science, vol. 2, no. 10, 2012.

[39] V. Lobo, A. Patil, A. Phatak, and N. Chandra, "Free radicals, antioxidants and functional foods: Impact on human health," Pharmacognosy Reviews, vol. 4, no. 8, pp. 118-126, 2010. 

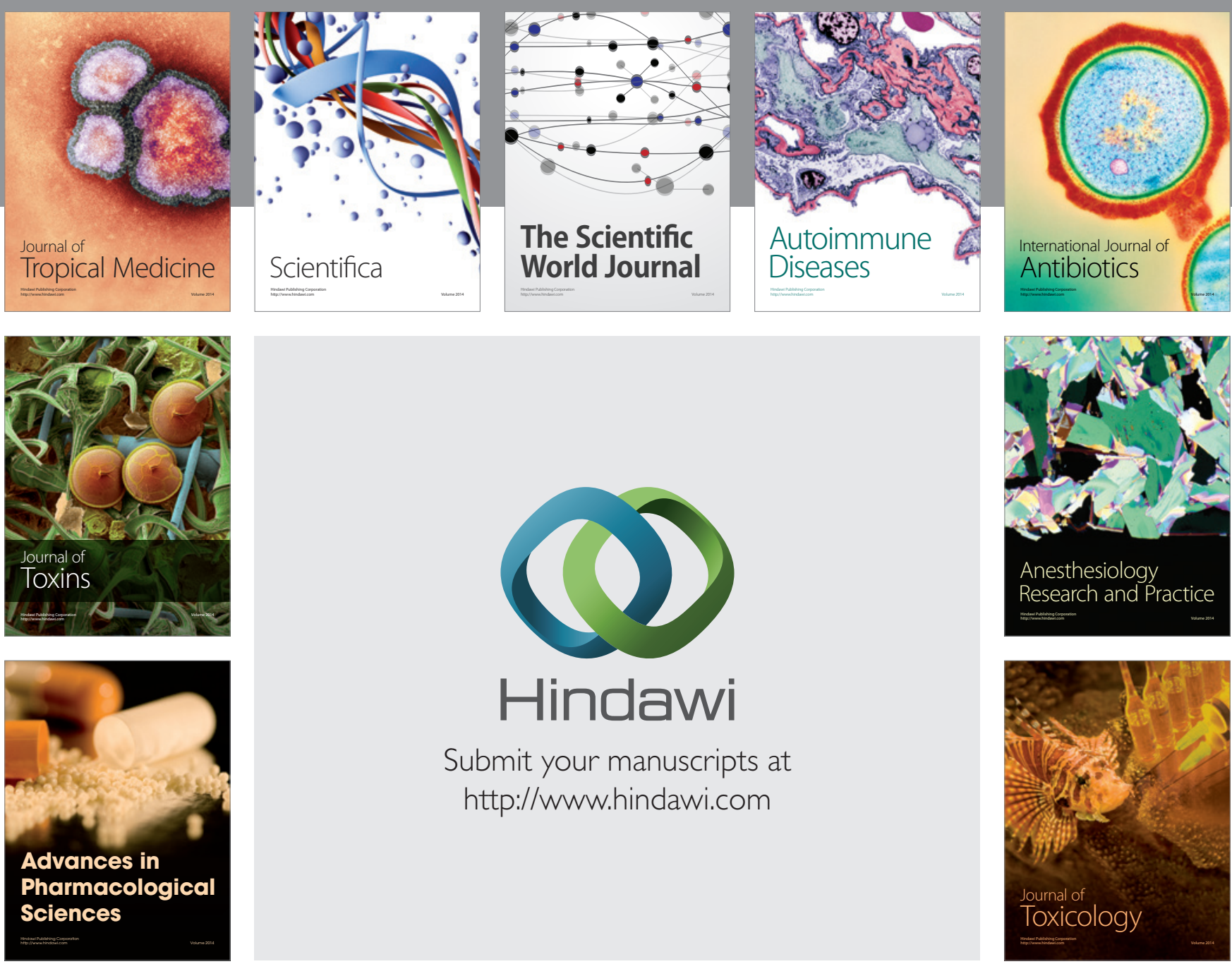

\section{Hindawi}

Submit your manuscripts at

http://www.hindawi.com
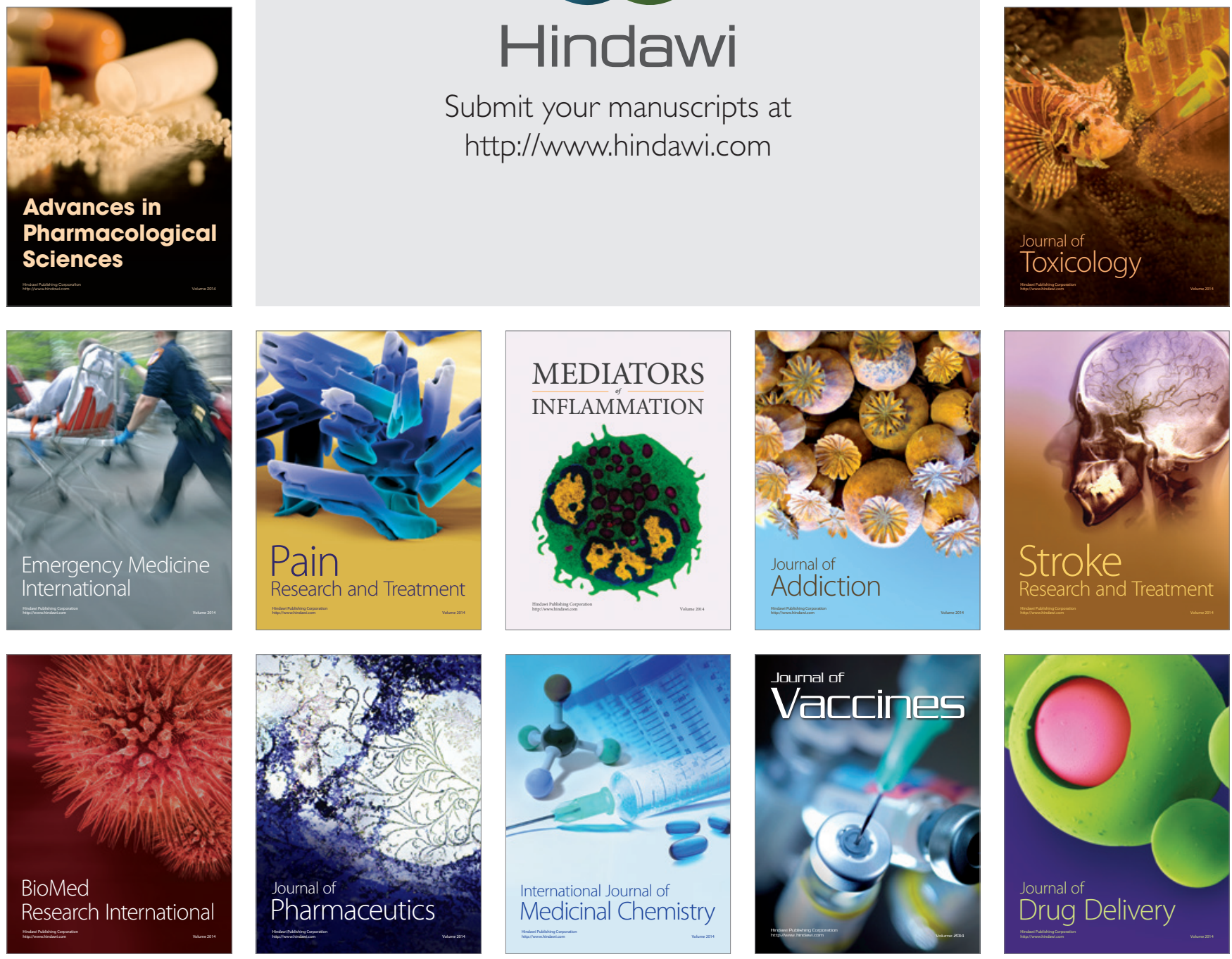